\title{
Effect of dabrafenib on melanoma cell lines harbouring the BRAF ${ }^{V 600 D / R}$ mutations
}

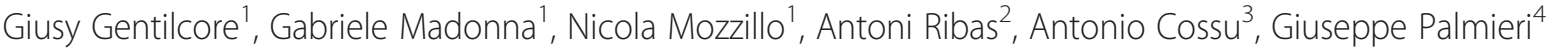 \\ and Paolo A Ascierto ${ }^{1,5^{*}}$
}

\begin{abstract}
Background: Conventional therapeutic agents are largely unsatisfactory into the treatment of malignant melanoma. Recently, an innovative approach based on inhibitors of the mutated BRAF gene (which represents the most prevalent alteration in melanoma patients) appears very promising from the clinical point of view. On this regard, a new compound, dabrafenib (GSK2118436), has been demonstrated to be effective in patients carrying the BRAFV600E/K mutations. We here tested dabrafenib for its capability to inhibit cell growth on primary melanoma cell lines, established from patients' tumour tissues and carrying the BRAFV600D/R mutations.
\end{abstract}

Methods: Three melanoma cell lines were tested: M257 wild-type BRAF, LCP BRAFV600R and WM266 BRAFV600D. The MTT assays were performed using standardized approaches. To evaluate the inhibition of MAPK pathway and the consequent inhibition of cellular proliferation, the phosphorylation of ERK was examined by Western Blot analysis performed on total protein extracts from cell lines after treatment with dabrafenib.

Results: Our experiments demonstrated an effective action of Dabrafenib (GSK2118436) and the inhibition of MAPK pathway in melanoma cell lines carrying BRAFV600D/R mutations.

Conclusion: These results could be helpful to enlarge the number of melanoma patients who may benefit of a more effective targeted treatment.

Keywords: BRAF inhibitor, Dabrafenib, Growth inhibition, Melanoma therapy

\section{Background}

The mitogen-activated protein kinase (MAPK) pathway is a key regulator of cell cycle progression, commonly activated in human tumours through somatic oncogenic mutations in $R A S, R A F$, and $M E K$ genes [1].

In melanoma, the most commonly mutated component of the MAPK pathway is the BRAF gene; among others, the most prevalent BRAF mutation (nearly, $90 \%$ of cases) is represented by a substitution of valine with glutamic acid at position 600 (V600E) [2]. This amino acid change leads to oncogenic activation of BRAF, with an increase of its kinase activity, and subsequent induction of phosphorylation of the downstream ERK protein.

\footnotetext{
* Correspondence: paolo.ascierto@gmail.com

'Department Melanoma, Istituto Nazionale Tumori Fondazione Pascale, Naples, Italy

${ }^{5}$ Unit of Medical Oncology and Innovative Therapy, Istituto Nazionale per lo Studio e la Cura dei Tumori "Fondazione G. Pascale", Via Mariano Semmola, 80131, Naples, Italy

Full list of author information is available at the end of the article
}

Constitutively activated ERK then stimulates cell proliferation and survival, sustaining tumour maintenance and growth [2]. The remaining BRAF mutations are mostly represented by other V600 subtypes (V600K, V600D, and V600R), which account for about $8 \%$ of the pathogenetic gene sequence variants [3]. In our experience, mutations in BRAF gene occur in $43 \%$ of primary melanomas and $48 \%$ of metastatic melanomas [4].

A significant benefit in melanoma treatment has been recently achieved with two selective inhibitors: vemurafenib (PLX4032), which seems to particularly act on $\mathrm{BRAF}^{\mathrm{V} 600 \mathrm{E}}$ mutants (although it has been demonstrated to also inhibit proliferation of melanoma cell lines expressing other codon 600 BRAF mutations: V600D, V600K, and V600R) [5-7], and dabrafenib (GSK2118436), which has been demonstrated to mostly inhibit the kinase activity in $\mathrm{BRAF}^{\mathrm{V} 600 \mathrm{E} / \mathrm{K}}$ mutants $[8,9]$.

To investigate whether this latter compound may exert inhibiting effects on a wider range of BRAF mutants

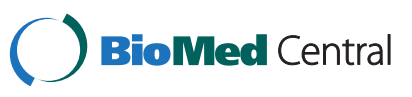


(similarly to those previously reported with vemurafenib/PLX4720 [5,7]), melanoma cell lines carrying the two remaining most prevalent BRAF mutations (V600D and V600R) were here treated with dabrafenib and cellular proliferation was then assessed.

\section{Methods}

To determine effects on proliferation, melanoma cell lines were treated in triplicate with increasing concentrations ( 3 to $100 \mathrm{nM}$ ) of dabrafenib for 72 hrs. To evaluate the occurrence of inhibitory effects on the ERK activation, a Western Blot analysis was performed on total proteins extracted from cell lines after the 72-hrs treatment with the BRAF inhibitor. In particular, the rate of phosphorylated ERK was estimated on equal amounts of total protein for cell lysates; GAPDH was used as an internal control for total protein expression levels. Cell doubling time was determined from cell numbers measured in duplicates every 24 hours for a period of 7 days, using Burker cell counts.

\section{Results and discussion}

Using a panel of melanoma cell lines derived from the establishment of excised primary and metastatic tumours, we have investigated the ability of dabrafenib to both exert an antiproliferative activity on cultured melanoma cells and block the ERK signalling induced by the mutated BRAF. In our assay, the LCP melanoma cell line carried the $\mathrm{BRAF}^{\mathrm{V} 600 \mathrm{R}}$ mutation, whereas the WM266 melanoma cell line presented the $\mathrm{BRAF}^{\mathrm{V} 600 \mathrm{D}}$ variant (Figure 1A); the M257 melanoma cell line, with a wild-type BRAF, was used as control.

In our series, dabrafenib showed a remarkable inhibition of cell proliferation in both melanoma cell lines carrying a mutated BRAF (regardless of the type of mutation, $\mathrm{BRAF}^{\mathrm{V} 600 \mathrm{D}}$ or $\mathrm{BRAF}^{\mathrm{V} 600 \mathrm{R}}$ ), with lack of significant

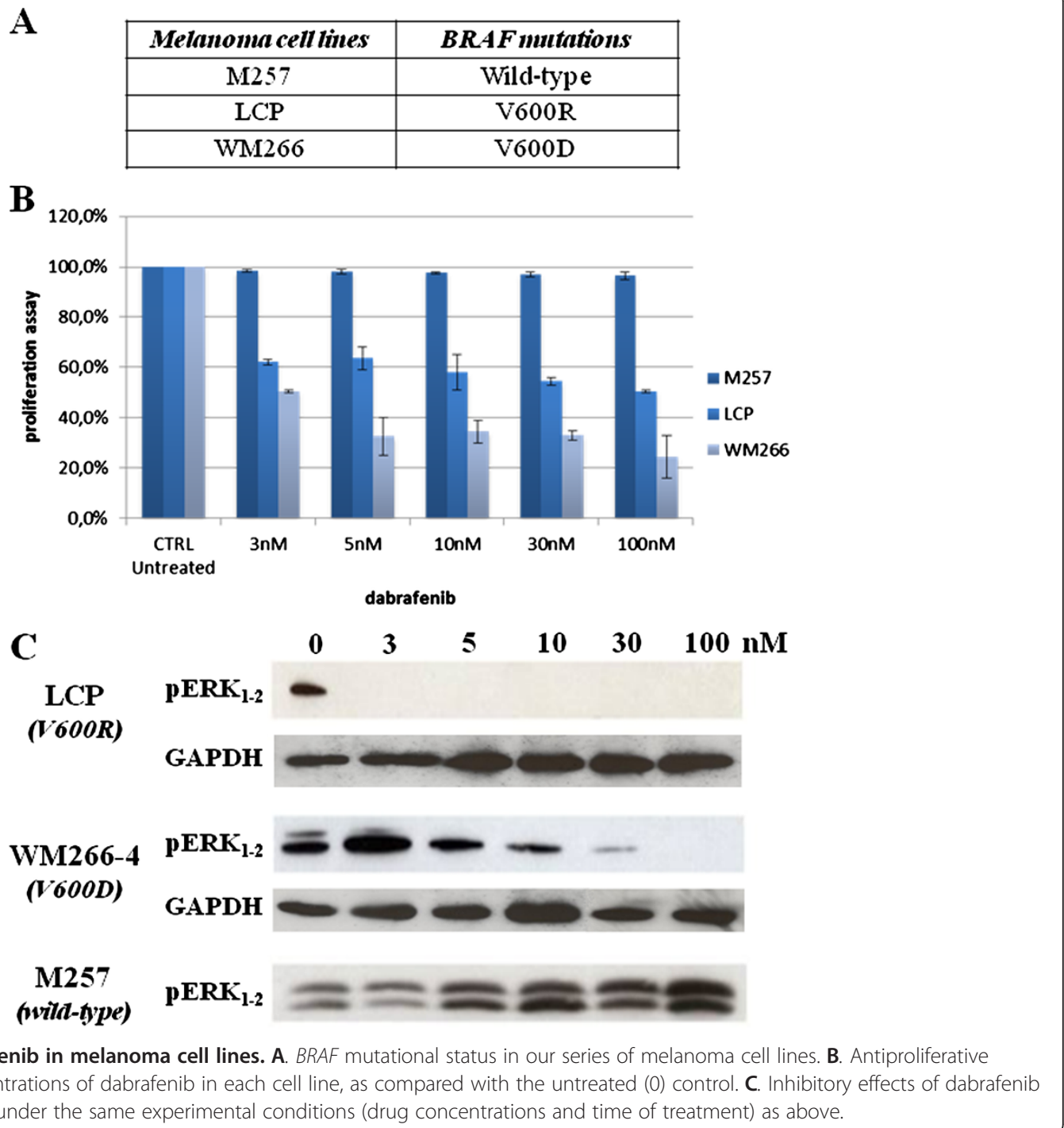

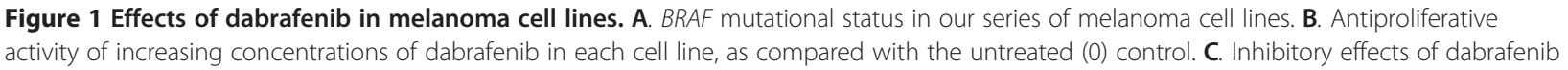
on ERK $_{1-2}$ phosphorylation, under the same experimental conditions (drug concentrations and time of treatment) as above. 
antiproliferative effects in control cells presenting a wildtype BRAF (Figure 1B). Regarding the interference with the ERK signaling, cell lines with $\mathrm{BRAF}^{\mathrm{V} 600 \mathrm{D} / \mathrm{R}}$ mutations presented a faster and stronger inhibition of phosphorylated ERK as compared to control cells with a wild-type $B R A F$ (Figure 1C).

Dabrafenib has been reported to be specifically active on $\mathrm{BRAF}^{\mathrm{V} 600 \mathrm{E} / \mathrm{K}}$ mutants; data here presented strongly suggest that $\mathrm{BRAF}^{\mathrm{V} 600 \mathrm{D} / \mathrm{R}}$ mutations might be also included as an effective target of the drug. Nevertheless, although the $\mathrm{BRAF}^{\mathrm{V} 600 \mathrm{D} / \mathrm{R}}$ mutations constitute a small fraction of the entire set of oncogenic variants in BRAF gene, the availability of a drug showing effectiveness on a more inclusive variety of BRAF-mutated targets could be helpful from the practical point of view, allowing clinicians to enlarge the subset of melanoma patients who may benefit of a more effective targeted treatment.

\section{Conclusions}

Although carried out on a limited series of melanoma cell lines, our study provided evidence that dabrafenib may exert a wider inhibitory activity on oncogenic variants of $B R A F$.

\section{Abbreviation \\ MAPK: Mitogen-activated protein kinase.}

\section{Competing interests}

Dr Paolo A. Ascierto participated to Advisory Board from Bristol Myers Squibb, MSD, Roche Genentech, GSK, and received honoraria from Brystol Myers Squibb, MSD and Roche-Genentech. All remaining authors declare the absence of any Competing Interest.

\section{Authors' contributions}

GG performed data acquisition, data analysis, preparation of the illustration, and drafted the manuscript; GM contributed in data analysis and draft of the manuscript; NM contributed in interpretation of the data; AR critically revised the manuscript; AC contributed in data analysis; GP collaborated in the draft of the manuscript; PAA conceived and supervised the study, and revised the manuscript. All authors read and approved the final version of the manuscript.

\section{Acknowledgments}

Authors thank Glaxo Smith and Kline for providing the dabrafenib for this study. A special thanks to the Fondazione Melanoma Onlus for partially grant the present work.

\begin{abstract}
Author details
'Department Melanoma, Istituto Nazionale Tumori Fondazione Pascale, Naples, Italy. ${ }^{2}$ Department of Medicine, Jonsson Comprehensive Cancer Center, UCLA, Los Angeles, CA, USA. ${ }^{3}$ Department of Pathology, Hospital-University Health Unit (AOU), Sassari, Italy. ${ }^{4}$ Institute of Biomolecular Chemistry, National Research Council (ICB-CNR), Sassari, Italy. ${ }^{5}$ Unit of Medical Oncology and Innovative Therapy, Istituto Nazionale per lo Studio e la Cura dei Tumori "Fondazione G. Pascale", Via Mariano Semmola, 80131, Naples, Italy.
\end{abstract}

Received: 25 March 2012 Accepted: 13 November 2012

Published: 14 January 2013

\section{References}

1. Nissan MH, Solit DB: The "SWOT" of BRAF inhibition in melanoma: RAF inhibitors, MEK inhibitors or both? Curr Oncol Rep 2011, 13:479-487.
2. Davies $H$, Bignell GR, Cox $C$, et al: Mutations of the BRAF gene in human cancer. Nature 2002, 417:949-954.

3. Menzies AM, Haydu LE, Visintin L, Carlino MS, Howle JR, Thompson JF, Kefford RF, Scolyer RA, Long GV: Distinguishing Clinicopathologic Features of Patients with V600E and V600K BRAF-Mutant Metastatic Melanoma. Clin Cancer Res 2012, 18:3242-3249.

4. Colombino M, Capone M, Lissia A, Cossu A, Rubino C, De Giorgi V, Massi D, Fonsatti E, Staibano S, Nappi O, Pagani E, Casula M, Manca A, Sini MC, Franco R, Botti G, Caracò C, Mozzillo N, Ascierto PA, Palmieri G: BRAF/NRAS mutation frequencies among primary tumors and metastases in patients with melanoma. J Clin Oncol 2012, 30:2522-2529.

5. Yang H, Higgins B, Kolinsky K, Packman K, Go Z, lyer R, Kolis S, Zhao S, Lee R, Grippo JF, Schostack K, Simcox ME, Heimbrook D, Bollag G, Su F: RG7204 (PLX4032), a selective BRAFV600E inhibitor, displays potent antitumor activity in preclinical melanoma models. Cancer Res 2010, 70:5518-5527.

6. Chapman PB, Hauschild A, Robert C, Haanen JB, Ascierto P, Larkin J, Dummer R, Garbe C, Testori A, Maio M, Hogg D, Lorigan P, Lebbe C, Jouary T, Schadendorf D, Ribas A, O'Day SJ, Sosman JA, Kirkwood JM, Eggermont AM, Dreno B, Nolop K, Li J, Nelson B, Hou J, Lee RJ, Flaherty KT, McArthur GA, BRIM-3 Study Group: Improved survival with vemurafenib in melanoma with BRAF V600E mutation. N Engl J Med 2011, 364:2507-2516.

7. Deng W, Gopal YN, Scott A, Chen G, Woodman SE, Davies MA: Role and therapeutic potential of PI3K-mTOR signaling in de novo resistance to BRAF inhibition. Pigment Cell Melanoma Res 2012, 25:248-258.

8. Trefzer UD, Minor D, Ribas A, Lebbe C, Siegfried A, Arya N, Guckert M, Schadendorf D, Kefford R, Grob JJ, Hamid O, Amaravadi R, Simeone E, TWilhelm T, Kim K, Goodman V, Ascierto PA: BREAK-2: a phase IIA trial of the selective BRAF kinase inhibitor GSK2 118436 in patients with BRAF mutation-positive (V600E/K) metastatic melanoma. Pigment Cell Res 2011, 24:1020. abstract LBA1-1.

9. Falchook GS, Long GV, Kurzrock R, Kim KB, Arkenau TH, Brown MP, Hamid O, Infante JR, Millward M, Pavlick AC, O'Day SJ, Blackman SC, Curtis CM, Lebowitz P, Ma B, Ouellet D, Kefford RF: Dabrafenib in patients with melanoma, untreated brain metastases, and other solid tumours: a phase 1 dose-escalation trial. Lancet 2012, 379:1893-1901.

doi:10.1186/1471-2407-13-17

Cite this article as: Gentilcore et al. Effect of dabrafenib on melanoma cell lines harbouring the BRAF ${ }^{V 600 D / R}$ mutations. BMC Cancer 2013 13:17.

\section{Submit your next manuscript to BioMed Central and take full advantage of:}

- Convenient online submission

- Thorough peer review

- No space constraints or color figure charges

- Immediate publication on acceptance

- Inclusion in PubMed, CAS, Scopus and Google Scholar

- Research which is freely available for redistribution 